\title{
Politik Kewarganegaraan Masyarakat Kelurahan Kisaran Naga (Studi Kasus Pada Pemilihan Calon Anggota DPRD Kabupaten Asahan Tahun 2019)
}

\author{
Juli Natalia Silalahi ${ }^{1}$ \\ ${ }^{1}$ Dosen Program Studi Sosiologi, Universitas Palangka Raya, Indonesia \\ Email: julinataliasilalahi12@fisip.upr.ac.id
}

\begin{abstract}
The purpose of this study was to analyze the politics of citizenship (liberal or democratic) in the Kisaran Naga Village Society in the context of the Election of Prospective Members of the Asahan Regency DPRD in 2019. This study used a qualitative research method with a case study approach to the citizenship politics in the community of Kisaran Naga, Kota Kisaran Timur District, Asahan Regency. Data collection techniques through observation, in-depth interviews and secondary data collection. Data validity uses multiple sources of evidence from expert informants, ordinary informants, and secondary data. Data analysis with an interactive model that is data reduction, data presentation, and drawing conclusions. The results of this study are contextual that occurs in citizens in the village of Kisaran Naga in understanding the legislative elections of Asahan Regency in Electoral District 1 is still a liberal citizenship. That is, citizens still understand the legislative election as a capitalist movement (money politics), identity political movement (religion, ethnicity (clan)) so that the condition affects the understanding of citizens not to give too much concern to the running of democratic legislative elections. The movement to reject money politics as the basis of the capitalist movement is evident in 1 subject of informants, but the condition still falls on the choice of citizens who choose candidates based on identity politics. So, liberal citizenship is still quite strong in the tradition of citizens in the Kisaran Naga Village.
\end{abstract}

\section{Keywords : Politics Of Citizenship; Democratic Citizenship; Citizens; Legislative Election}

Abstrak. Tujuan penelitian ini untuk menganalisis politik kewarganegaraan (liberal atau demokratik) pada Masyarakat Kelurahan Kisaran Naga dalam konteks Pemilihan Calon Anggota DPRD Kabupaten Asahan Tahun 2019. Penelitian ini menggunakan metode penelitian kualitatif dengan pendekatan studi kasus politik kewarganegaraan masyarakat di Kelurahan Kisaran Naga, Kecamatan Kota Kisaran Timur, Kabupaten Asahan. Teknik pengumpulan data melalui observasi, wawancara mendalam dan pengumpulan data sekunder. Untuk validitas data menggunakan multi sumber bukti baik dari informan ahli, informan biasa, maupun dari data sekunder. Analisis data dengan model interaktif yaitu reduksi data, penyajian data, dan penarikan kesimpulan. Hasil penelitian ini yaitu Kontekstual yang terjadi pada warga di Kelurahan Kisaran Naga dalam memahami Pemilihan Legislatif Kabupaten Asahan di Dapil 1 masih bersifat pada kewarganegaraan liberal. Artinya, warga negara masih memahami Pemilihan Legislatif sebagai gerakan kapitalis (politik uang), gerakan politik identitas (agama, suku (marga)) sehingga kondisi itu berdampak pada pemahaman warga untuk tidak terlalu memberikan kepedulian tinggi pada berjalannya Pemilihan Legislatif yang demokratik. Gerakan untuk menolak politik uang sebagai basis gerakan kapitalis memang terlihat pada 1 subjek informan, akan tetapi kondisi itu pun tetap jatuh pada pilihan warga tersebut yang memilih Caleg berdasarkan politik identitas. Jadi, kewarganegaraan liberal masih cukup kuat dalam tradisi warga di Kelurahan Kisaran Naga.

Kata Kunci : Politik Kewarganegaraan, Kewarganegaraan Demokratik, Warga Negara, Pemilihan Legislatif 


\section{PENDAHULUAN}

Kelurahan Kisaran Naga, Kecamatan Kota Kisaran Timur, Kabupaten Asahan, Provinsi Sumatera Utara merupakan salah satu daerah yang memiliki partisipasi politik tinggi dalam pemilihan calon legislatif (DPRD) Kabupaten Asahan wilayah Kelurahan Kisaran Naga. Adapun Daftar Pemilih Tetap di Kelurahan berjumlah 5313 Orang, sedangkan pengguna hak pilih berjumlah 3272 orang. Artinya partisipasi politik masyarakat Kisaran Naga cukup tinggi yaitu lebih dari 50\%. (KPU, 2019).

Menurut Liando (2016: 21) bahwa partisipasi politik tinggi dapat dipengaruhi beberapa latar filosofis, yaitu dipengaruhi oleh visi misi partai politik dan calon, dipengaruhi oleh pemberian uang atau bingkisan lain, memiliki hubungan darah atau terikat saudara dengan calon, memiliki kesamaaan etnik dengan calon, memiliki kesamaan keyakinan agama/golongan kepercayaan dengan calon, karena adanya permintaan orang tua atau kerabat, memiliki kesamaan profesi dengan profesi calon, kesenangan/simpati informan dengan calon, kesenangan/simpati informan dengan calon. Partisipasi politik tinggi lahir dari beberapa pilihan rasional, yaitu lahir dari tindakan pragmatis atau kritis terhadap pilihan Caleg. Tindakan pragmatis atau kritis pun hadir dari partisipasi secara personal individu maupun sugesti dari aktor-aktor politik.

Pada konteks masyarakat Kelurahan Kisaran Naga, partisipasi suara masyarakat pada pilihan Parpol dalam PILEG Kabupaten Asahan didominasi oleh Partai Amanat Nasional (PAN) sekitar 23\%, lalu diikuti oleh PKS dan PKPI diatas rata-rata 11\% (KPU, 2019). Ketiga partai memiliki andil besar terhadap perkembangan pendidikan politik masyarakat Kisaran Naga. Peningkatan persentase suara pada Partai PAN, PKS, dan PKPI di Kabupaten Asahan dapat dipengaruhi oleh gerakan massa dari partai politik untuk meyakinkan masyarakat, gerakan massa dari pemerintah, gerakan sosial dari lingkungan masyarakat. Peningkatan persentase suara masyarakat ke parpol yang mendominasi harusnya bisa seimbang dengan kualitas pendidikan politik Parpol terhadap masyarakat. Parpol menjadi komunitas politik yang membimbing masyarakat terhadap kemerdekaan pilihan.

Politik Kewarganegaraan Demokratik merupakan tawaran terhadap pengembangan kemerdekaan pilihan warga negara, dalam hal ini yaitu gerakan aktif pemilih dalam PILEG 2019 di Kelurahan Kisaran Naga Kabupaten Asahan. Laku hidup warga negara pada rezim ini menawarkan analisis sejauh mana hak dan kewajiban sebagai warga negara berjalan sebagai kesadaran bukan sebagai ketegangan. Kebebasan warga negara hadir atas perjuangan warga negara maupun dukungan dari komunitas politik, misalnya Parpol, Pemerintah, LSM, dan gerakan sosial masyarakat. Akan tetapi, Kebebasan warga negara hadir bukan sebagai dominasi dari komunitas politik. Bagaimana konteks pada masyarakat Kisaran Naga? Apakah politik kewarganegaraan masyarakat hadir secara demokratik? Atau yang mendominasi adalah gerakan pasar kapitalisme (politik kewarganegaraan liberal), seperti money politics, Isu SARA, dan politik identitas.

\section{METODE PENELITIAN}

Penelitian ini menggunakan metode penelitian kualitatif dengan pendekatan studi kasus politik kewarganegaraan masyarakat di Kelurahan Kisaran Naga, Kecamatan Kota Kisaran Timur, Kabupaten Asahan. Teknik pengumpulan data melalui observasi, wawancara mendalam dan pengumpulan data sekunder. Untuk validitas data menggunakan multi sumber bukti baik dari informan ahli, informan biasa, maupun dari data sekunder. Analisis data dengan model interaktif yaitu reduksi data, penyajian data, dan penarikan kesimpulan. (Creswell, 2015 : 222 ; Denzin, 2009: 309).

Penelitian ini dilaksanakan mulai tanggal 18 Desember 2019 - 12 Januari 2020. Fokus penelitian ini di Kelurahan Kisaran Naga, Kecamatan Kota Kisaran Timur, Kabupaten Asahan, Provinsi Sumatera Utara. Arah penelitian pada PILEG Anggota DPRD Kabupaten Asahan Daerah Pemilihan ASAHAN 1 Tahun 2019.

Adapun informan yang akan diwawancarai yaitu 4 orang warga biasa masyarakat Kelurahan Kisaran Naga, 1 orang anggota DPRD ASAHAN 1 dari PKPI, Lurah Kelurahan Kisaran Naga/ mewakili. Tujuan mewawancarai masyarakat Kelurahan Kisaran Naga yaitu untuk mengetahui secara subjektif bagaimana laku hidup masyarakat dalam memahami hak dan kewajiban sebagai warga negara yang bebas dan peduli memberikan pilihan suara terhadap Caleg DPRD Kabupaten Asahan. Laku hidup yang dilandasai dengan 
kepedulian terhadap pentingnya komunitas politik sebagai pendukung kedaulatan warga dalam menentukan pilihan Caleg. Laku hidup akan pentingnya kesadaran hadir atas hak dan kewajiban sebagai warga negara yang aktif mengartikulasikan/ memperjuangkan pilihan politik pada Caleg.

Adapun tujuan mewawancarai anggota DPRD ASAHAN 1 dari PKPI yaitu untuk mengetahui bagaimana peran komunitas politik dari utusan parpol dalam memberikan pendidikan politik kewarganegaraan demokratik kepada masyarakat Kelurahan Kisaran Naga. Laku hidup yang tampil bukanlah politik kewarganegaraan liberal yang sarat akan gerakan pasar (money politics, isu SARA, politik identitas) akan tetapi kepada politik kewarganegaraan demokratik, yaitu pendidikan politik yang mengidentifikasi setiap warga memiliki kebebasan dan kepedulian terhadap hak politiknya. Setiap warga di Kelurahan Pahandut Seberang memiliki kesadaran akan hak dan kewajiban terhadap demokrasi radikal, bukan hak dan kewajiban yang hadir dari demokrasi modern/liberal.

Adapun tujuan mewawancarai aparat Kelurahan Kisaran Naga adalah untuk mengetahui sejauhmana pandangan pemerintah melihat perkembangan politik kewarganegaraan masyarakatnya. Sejauhmana kepedulian pemerintah terhadap kebebasan dan kepedulian masyarakatnya terhadap hak dan kewajiban politik. Singkatnya, sejauhmana peran Kelurahan Kisaran Naga memberikan pendidikan politik kewarganegaraan demokratik terhadap masyarakatnya.

\section{HASIL DAN PEMBAHASAN}

\section{A. Politik Kewarganegaraan Liberal Pada Masyarakat Kelurahan Kisaran Naga}

Politik kewarganegaraan demokratik dan Politik kewarganegaraan liberal adalah dua hal yang berbeda. Pada tataran politik kewarganegaraan liberal, warga memahami identitas politik, artikulasi politik, dan komunitas politik sebagai status terberi dan pasif, dan tingggal Negara yang memberikan perjuangan. Namun, politik kewarganegaraan demokratik merupakan warga adalah subjek yang aktif mengidentifikasi diri dalam komunitas politik, dan mengakui prinsip-prinsip etik-politik dalam komunitas politik, serta memiliki pemahaman akan hak-hak dan konsepsi tentang keadilan. Dengan demikian, kewarganegaraan bukanlah status legal tetapi suatu bentuk identifikasi, sesuatu yang dibentuk, bukan secara empiris terberi. Tetapi, perlu diketahui, bahwa komunitas politik itu penting dalam membentuk prinsip etik-politik pada subjek warga negara. Sebab, komunitas politiklah yang memberi tuntunan atau pedoman bagi individu untuk memaknai dan memperjuangkan hak-haknya dalam formasi identitas politik kolektif. (Suryadinata, 2017:22-23)

Pandangan demokrasi radikal, distingsi privat/publik mesti dirumuskan ulang. Distingsi antara privat (kebebasan individu) dan publik (respublica) tetap dijaga seperti distingsi individu/ citizen, tetapi tidak ada ruang pemisah diantaranya. Keinginan dan keputusan tetap bersifat pribadi karena itu merupakan tanggung jawab pribadi, tetapi penampilannya ke publik mesti mempertimbangkan kondisi tertentu dalam komunitas politik (respublica). Selama komunitas politik tidak mendikte individu tentang apa yang harus dilakukan, dengan kata lain tidak otoriter, komunitas politik tersebut tetap respek terhadap kebebasan pribadi. (Suryadinata, 2017:24).

Seseorang tidak bisa mengatakan disini kewajibanku sebagai warga berakhir dan kebebasan pribadi dimulai. Dua identitas ini berada dalam tegangan permanen yang tidak pernah bisa didamaikan. Lebih tepatnya, ini merupakan tegangan antara konsep kebebasan dan konsep kesetaraan yang merupakan karakter demokrasi modern (liberal). Oleh karena itu, proyek demokrasi radikal mengakui ketakmungkinan realisasi yang lengkap dari demokrasi dan pencapaian yang final dari komunitas politik. Demokrasi radikal menggunakan sumber daya simbolik dari tradisi demokrasi liberal untuk memperdalam revolusi demokrasi, sambil mengetahui bahwa hal ini merupakan proses yang tidak pernah selesai. Ideal tentang kewarganegaraan dapat berkontribusi besar bagi pemahaman akan tegangan antara prinsip kebebasan (liberty) dan kesetaraan (equality). (Suryadinata, 2017:24)

Konsep kewarganegaraan demokratik yang menekankan peran komunitas politik tanpa mengorbankan kebebasan individu memberi tempat bagi pembicaraan tentang keagenan subjek politik dan pembentukan identitas politik kolektif. Individu dibayangkan disini sebagai warga negara yang aktif memperjuangkan dan memaknai hak-haknya dalam komunitas politik pada semangat 
kesetaraan dan kebebasan dengan yang lain. Konsep seperti ini sesuai dengan konsep keadilan yang memuat elemen-elemen seperti pengakuan dan partisipasi yang sering diabaikan oleh liberalisme. (Suryadinata, 2017:24-25)

Laku hidup aktif sebagai warga negara dan komunitas politik dapat terlihat dalam fenomena politik saat ini yaitu pemilihan legislatif tingkat daerah. Dalam hal ini, pemilihan calon anggota DPRD Kabupaten Asahan Tahun 2019 di Dapil 1 (Secara khusus di Kelurahan Kisaran Naga, Kecamatan Kota Kisaran Timur). Pemilihan Legislatif harusnya menjadi ruang pesta demokrasi bagi pemilih dalam menyatakan pilihan politiknya secara bebas, demokratis, dan menjunjung nilai integritas sebagai pemilih. Pemilih harusnya bebas dalam mencari informasi jejak rekam anggota caleg DPRD Dapil 1 Kabupaten Asahan yang akan terpilih. Pemilih harusnya secara aktif mengetahui latar belakang caleg, visi dan misi, partai politik si caleg, bidang yang ditekuni caleg, jejak rekam si caleg.

Seperti menurut Mouffe dalam suryadinata, (2017:23) bahwa komunitas politik itu penting, karena komunitas politiklah yang memberi tuntunan atau pedoman bagi individu untuk memaknai dan memperjuangkan hak-haknya dalam formasi identitas politik kolektif. Namun, apa yang terjadi apabila komunitas politik tidak memberikan pendidikan politik kepada warga negara. Warga negara harusnya mendapatkan pendidikan politik sebagai pemilih dalam pileg Kabupaten Asahan. Pendidikan politik itu bisa dari pemerintah Kelurahan Kisaran Naga, caleg di Kecamatan Kota Kisaran Timur, Lembaga Swadaya Masyarakat (LSM), dan komunitas peduli pemilu. Tetapi, pada realitas nya, warga di Kelurahan Kisaran Naga tidak diberikan pendidikan politik selama masa-masa PILEG itu berlangsung. Warga dibiarkan dengan narasi-narasi yang dibangun oleh para caleg dan parpol, serta tim sukses, tanpa filter dari pemerintah maupun LSM.

Kondisi diatas lah yang membuat banyak warga di Kelurahan Kisaran Naga membuat sikap tidak berkontribusi penuh pada PILEG Kab. Asahan yang berintegritas. Berikut data penelitian terkait alasan warga Kelurahan Kisaran Naga mencoblos pada PILEG Kabupaten Asahan Tahun 2019 di Dapil 1 (Kelurahan Kisaran Naga).

Tabel 1.1 Alasan Warga Mencoblos Pada PILEG Kabupaten Asahan Tahun 2019 Dapil 1

\begin{tabular}{|c|c|c|c|}
\hline No & Nama & Pilihan Caleg & Alasan Mencoblos \\
\hline 1 & Ibu Simarmata & Polman Simarmata & \multirow{4}{*}{$\begin{array}{l}\text { 1. Mengenal Caleg } \\
\text { 2. Sesama Marga (Suku) } \\
\text { 3. Sesama Agama } \\
\text { 4. Memperoleh Uang }\end{array}$} \\
\hline & & & \\
\hline & & & \\
\hline & & & \\
\hline \multirow[t]{6}{*}{2.} & Ibu Nadapdap & Boro & \multirow{6}{*}{$\begin{array}{l}\text { 1. Memperoleh uang } \\
\text { 2. Para Caleg berambisi } \\
\text { ingin menang } \\
\text { 3. Sesama Suku } \\
\text { 4. Sesama Agama } \\
\text { 5. Ada keterkaitan } \\
\text { kekeluragaan }\end{array}$} \\
\hline & & & \\
\hline & & & \\
\hline & & & \\
\hline & & & \\
\hline & & & \\
\hline \multirow{5}{*}{3.} & Namboru Molek & Fdward Simaniuntak & 1 Visi misi hagus \\
\hline & & & 2. Memperjuangkan hak \\
\hline & & & agama Kristen \\
\hline & & & (Pembangunan \\
\hline & & & pekuburan Kristen) \\
\hline \multirow[t]{4}{*}{4.} & Nantulang Nahan & Polman Simarmata & 1. Memperoleh uang \\
\hline & & & 2. Solidaritas sosial yang \\
\hline & & & kuat \\
\hline & & & $\begin{array}{l}\text { 3. Memiliki komunikasi } \\
\text { politik yang baik }\end{array}$ \\
\hline
\end{tabular}


Selain pendapat warga tentang mencoblos, disini juga ditampilkan pendapat Lurah Kisaran Naga dan anggota DPRD Kabupaten Asahan dalam pandangannya terhadap PILEG 2019 di Kabupaten Asahan (Kelurahan Kisaran Naga).

Tabel 1.2 Pandangan Lurah Kisaran Naga dan Anggota DPRD Kabupaten Asahan Terhadap PILEG

\begin{tabular}{|c|c|c|c|}
\hline No & Nama & Jabatan & Alasan warga mencoblos \\
\hline \multirow[t]{4}{*}{1} & Marianto & Lurah Kisaran Naga & $\begin{array}{l}\text { 1. Warga memilih } \\
\text { berdasarkan se marga (se } \\
\text { suku) }\end{array}$ \\
\hline & & & $\begin{array}{ll}\text { 2. } & \text { Warga memilih } \\
& \text { berdasarkan seagama }\end{array}$ \\
\hline & & & 3. Warga menerima uang \\
\hline & & & $\begin{array}{l}\text { 4. Warga jarang mau } \\
\text { menerima visi dan misi } \\
\text { Caleg. }\end{array}$ \\
\hline 2. & Polman Simarmata & $\begin{array}{lr}\text { Anggota } & \text { DPRD } \\
\text { Kabupaten } & \text { Asahan } \\
\text { Dapil 1 } & \end{array}$ & $\begin{array}{l}\text { 1. Kekeluargaan (Parsataon/ } \\
\text { kumpulan marga) } \\
\text { 2. Politik Uang } \\
\text { 3. Menaikkan kelompok } \\
\text { Kristen } \\
\text { 4. Ketokohan (Tokoh yang } \\
\text { mampu menjawab } \\
\text { kepentingan warga) } \\
\text { 5. Pergaulan / komunikasi }\end{array}$ \\
\hline
\end{tabular}

Sumber : Wawancara dalam penelitian, 2019.

Berdasarkan data diatas menunjukkan bahwa warga Kelurahan Kisaran Naga masih belum memahami PILEG sebagai hak politik aktif, dan warga masih jauh dari komunitas politik. Hak politik yang dimaksud disini adalah warga masih belum aktif memaknai PILEG di Kabupaten Asahan. Warga masih terjebak dengan urusan kepentingan individu dan golongan. Misalnya, memilih Caleg berdasarkan politik kepentingan individu dan keluraga si pemilih. Warga masih memahami bahwa kepentingan golongan yang dicita-citakan oleh si caleg dapat memberikan kebermanfaatan bagi si pemilih. Misalnya, rata-rata warga memilih Caleg berdasarkan sesama marga kumpulan Batak, sesama agama Kristen, si caleg mau memperjuangankan kelompok minoritas (agama Kristen), pemilih dengan caleg memiliki kedekatan secara emosional.

Warga Kelurahan Kisaran Naga memahami status kewarganegaraan pun sebagai pasif. Artinya, warga negara selalu menunggu hadirnya negara (Pemerintah) dalam perkembangan politik warga. Misalnya, warga Kelurahan Kisaran Naga tidak berkeinginan untuk mengetahui bagaimana perkembangan PILEG di Kabupaten Asahan, secara khsusus di Dapil 1. Bahkan, pencarian jejak rekam si Caleg pun warga tidak memperdulikan itu. Realitas sosial yang terjadi bahwa kepedulian pemerintah, LSM, Caleg untuk tumbuh kembangnya perpolitikan warga terhadap PILEG tidak berjalan dengan baik. Komunitas politik tidak pernah memberikan pendidikan politik kepada warga di Kelurahan Kisaran Naga. Namun, berdasarkan hasil wawancara dengan anggota DPRD dari fraksi PKPI (Polman Simarmata) menyatakan bahwa : 
Memang kami tidak pernah memberikan pendidikan politik, misalnya dalam bentuk Bimtek, tetapi kami memanfaatkan momen RESES untuk mengetahui apa sebenarnya mau nya warga. Kalau untuk pendidikan politik belum ada untuk warga, palingan hanya untuk kader saja yang ada. Mungkin untuk partai besar biasa mengadakan pendidikan politik, tetapi untuk partai seperti kami belum bisa, masih terbatas dengan keuangan. (Hasil wawancara, 03 Januari 2020).

Hasil wawancara diatas menunjukkan bahwa komunitas politik belum menjadi edukator politik bagi warga negara. Komunitas politik di Kelurahan Kisaran Naga masih berorientasi pada demokrasi liberal. Artinya, pendidikan politik bukanlah sesuatu yang penting untuk perkembangan kepedulian warga terhadap PILEG dan politik. Tetapi, mekanisme dan keberhasilan merebut suara warga di Kelurahan Kisaran Naga menjadi prioritas utama para caleg. Begitupun dengan komunitas politik dari pemerintah dan LSM yang ada di Kelurahan Kisaran Naga. Seperti tertuang dalam salah satu hasil wawancara dengan Ibu Nadapdap bahwa :

Tidak pernah diberikan pendidikan politik dari pemerintah untuk warga disini, dari LSM pun begitu. Jangankan pendidikan politik, jalan ini aja (jalan durian) mana ada diperbaiki, beras raskin itu pun gak tepat sasaran. Apalagi urusin pendidikan politik. Intinya warga disini itu gak mau tau tentang pendidikan politik dari siapa pun itu, yang penting kemauan warga terpenuhi. (Hasil wawancara, 03 Januari 2020).

Hasil wawancara diatas menunjukkan bahwa subjek memahami citizenship (kewarganegaraan) sebagai pasif. Warga Kisaran Naga memahami PILEG Anggota DPRD Dapil 1 Kabupaten Asahan sebagai ruang kosong, tidak memberikan dampak berarti bagi kehidupan sehari-hari warga. Warga Kisaran Naga pun menyikapi PILEG Kabupaten Asahan sebagai ruang kapitalis dalam setiap perkumpulan marga/suku, gereja, lingkungan tempat tinggal. Ruang kapitalis yang dimaksud adalah tersedianya uang / materi bagi warga terhadap jasa pilihan politik dalam pemilihan anggota DPRD Dapil 1 Kabupaten Asahan.

\section{Meningkatnya Money Politics}

Masyarakat yang menyatakan setuju dengan adanya politik uang dengan alasan ekonomi yaitu pemberian calon kepala daerah dalam bentuk uang sedikitnya dapat membantu beban kebutuhan sebagian warga. (Suprianto, dkk, 2016). Namun, bagaimana dengan masyarakat Kelurahan Kisaran Naga?, Apakah, persepsi pada politik uang hanya dikarenakan untuk kebutuhan ekonomi?

Masyarakat Kelurahan Kisaran Naga memahami Pileg Anggota DPRD Kabupaten Asahan di DAPIL 1 sebagai ruang kapitalis. Pemilihan Umum yang harusnya menjadi ranah pesta demokrasi bagi rakyat dalam memberikan pilihan politiknya pada wakil rakyat di DPRD, tetapi kondisi itu menjadi ruang pundi-pundi mengumpulkan keuntungan. Realitas politik yang terjadi pada masyarakat Kelurahan Kisaran Naga, terdapat 3 Orang informan (warga biasa Kelurahan Kisaran Naga) beserta anggota keluarganya memilih menerima uang dari Caleg yang dipilihnya. Adapun alasan dari ketiga informan tersebut dikarenakan caleg tersebut memberikan uang tes (uang jalan / salam tempel) sekitar Rp. 100.000-150.000/orang. Uang ini diberikan oleh tim sukses dari si Caleg.

Adapun hasil wawancara dengan Plt Lurah Kisaran Naga (Bapak Marianto) menyatakan bahwa kontestasi Pemilihan Caleg DPRD DAPIL 1 Kabupaten Asahan, secara khusus pemilihan di DPT Kelurahan Kisaran naga sangat sarat akan politik uang, dan jauh dari alasan warga memilih caleg karena visi-misi. Begitupun dengan pendapat dari Bapak Polman Simarmata (Anggota DPRD dari PKPI, Kabupaten Asahan di Dapil 1, menyatakan bahwa politik uang (pemberian Caleg) menjadi nomor urut ke dua yang membuat masyarakat memiliki animo tinggi untuk mencoblos ke TPS. Berikut hasil wawancara dengan Bapak Polman Simarmata, 
Adapun alasan warga di Kelurahan Kisaran Naga memiliki animo yang tinggi untuk datang ke TPS dalam memiliki Caleg pada PILEG Kabupaten Asahan Dapil 1 yaitu satu, alasan kekeluargaan. Kedua, money politics. Ketiga, politik identitas (menaikkan kelompok Kristen, se marga). Keempat, Ketokohan Caleg. Kelima, Pergaulan dan komunikasi si Caleg pada masyarakat.

Peningkatan politik uang sudah menjadi harapan bagi sebagian warga di Kelurahan Kisaran Naga. Dalam setiap pertemuan Caleg, tim sukses dengan warga di Kelurahan Kisaran Naga dalam menjelang PILEG Kabupaten Asahan, uang tempel selalu dipertanyakan oleh warga. Jika tidak ada kejelasan uang tempel, maka kebanyakan warga tidak mau untuk mengikuti pertemuan, bahkan tidak mau untuk mencoblos si Caleg tersebut.

\section{Meningkatnya Politik Identitas}

Politik identitas adalah ciri yang tak dapat dihindari dari demokrasi liberal, sebab sistem politik itulah yang memberikan ruang bagi tumbuhnya upaya-upaya kelompok dalam mengartikulasikan kepentingan dan tujuannya. (Pasaribu ; Prayogi, 2018:16). Kabupaten Asahan juga menjadi salah satu pusatnya politik identitas, seperti dalam pemilihan Gubernur dan Wakil Gubernur Sumatera Utara, Edy Rahmayadi dan Musa Rajekshah (Eramas) terpilih berdasarkan pemilih dari mayoritas beragama Islam, sekitar 224.950 suara masuk ke Eramas. Perolehan ini sesuai dengan misi kampanye Eramas yang memainkan politik identitas agama untuk merebut hati warga. (Pasaribu ; Prayogi, 2018:17). Bagaimana dengan, politik identitas yang dilakukan Calon Legislatif DPRD Kabupaten Asahan Tahun 2019 ?.

Peningkatan politik identitas pun terjadi pada warga di salah satu Kelurahan pada Kabupaten Asahan, yaitu Kelurahan Kisaran Naga. Dari 4 orang warga biasa di Kelurahan Kisaran Naga yang diwawancarai, terdapat 1 Orang warga yang ternyata tidak menerima uang dari Caleg. Tetapi, Warga tersebut memilih berdasarkan kepentingan agama Kristen (politik identitas), yaitu Caleg menjanjikan Pembangunan pekuburan Kristen di Sei Kamah, Kecamatan Sei Dadap, Kabupaten Asahan. Janji politik untuk perjuangan kepentingan agama Kristen oleh Caleg membuat warga membidiknya. Sebab, selama ini warga Kisaran Naga merasa menjadi kelompok minoritas yang tidak diakomodir kepentingannya oleh Anggota DPRD dan pemerintah selama ini. Selain itu, alasan se marga dengan Caleg juga menjadi faktor warga memilih Caleg tersebut, apalagi Caleg memiliki hubungan kekeluargaan dengan warga.

Adapun kedua informan yaitu warga biasa di Kelurahan Kisaran Naga mengakui bahwa royalitas Caleg dalam memberikan modal ekonomi kepada parsahutaon (anggota kumpulan sesama Batak dan beragama Kristen di satu lingkungan Kisaran Naga) menjadi nilai lebih bagi warga untuk memilih Caleg. Permainan politik identitas semakin kuat dan menjamur di Kelurahan Kisaran Naga, bahkan politik identitas itu menjadi pandangan politik bagi warga.

\section{B. Karakteristik Kewarganegaraan Demokratik}

\section{Warga Adalah Subjek Yang Aktif Mengidentifikasi Diri Dalam Komunitas Politik}

Warga negara di Kelurahan Kisaran Naga masih memahami kewarganegaraan sebagai demokrasi liberal, belum sampai kepada kewarganegaraan demokratik atau demokrasi radikal. Menurut Mouffe dalam Suryadinata, (2017 : 22) bahwa Warga adalah subjek yang aktif mengidentifikasi diri dalam komunitas politik. Kewarganegaraan bukanlah status legal, tetapi suatu bentuk identifikasi, sesuatu yang dibentuk (diperjuangkan), bukan secara empiris terberi. Jika secara kontekstual pada warga Kelurahan Kisaran Naga, warga mengidentifikasi diri secara pasif pada konteks pemilihan caleg Dapil 1 Kabupaten Asahan. Kondisi itu bisa terlihat pada suara warga yang bisa dikooptasi oleh Caleg (politik uang). Bahkan warga tidak terlalu ingin mencari tahu lebih jauh jejak rekam Caleg, bidang yang dikuasai dan perkiraan Caleg yang akan terpilih di DPRD masuk pada komisi dan bidang apa?. Warga hanya melihat Caleg dari sudut pandang materi (politik uang), marga, 
agama, kekeluargaan (politik identitas), serta keuntungan pribadi dan kelompok yang diperoleh warga jika memilih caleg tertentu.

\section{Komunitas Politik Memberi Tuntunan Atau Pedoman Bagi Warga Negara}

Menurut Mouffe dalam Suryadinata, (2017 : 22) bahwa komunitas politiklah yang memberi tuntunan atau pedoman bagi individu untuk memaknai dan memperjuangkan hak-haknya dalam formasi identitas politik. Pendapat Mouffe pun diperkuat oleh penelitian Silalahi, (2018 : 213), bahwa kewarganegaraan demokratik perlu ditegaskan bahwa komunitas dan entitas lain berperan menuntun warga negara agar aktif memperjuangkan dan memaknai hak-haknya sebagai warga negara dalam komunitas lanting. Namun, pada konteks warga Kelurahan Kisaran Naga, komunitas politik (Pemerintah Kelurahan Kisaran Naga) bahkan legislatif (DPRD Fraksi PKPI di DAPIL 1 Kabupaten Asahan) tidak memiliki program untuk memberikan pendidikan politik terkait sikap warga dalam menyikapi PILEG.

Pemerintah (Kelurahan) pun menganggap ini bukan sebagai tugas mereka, Kelurahan bersifat adiminstratif. Begitu pula dengan DPRD Kabupaten Asahan dari Fraksi PKPI mengganggap bahwa pemberian pendidikan politik pada warga belum menjadi program, sebab dalam pandangan mereka bahwa reses sebagai pengganti pendidikan politik. Padahal reses dan pendidikan politik adalah situasi yang berbeda. Sebagai pembandingnya, menurut (Asnawi, $2016: 775$ ) bahwa, peserta Pemilu calon anggota legislatif, tidak memahami apa arti demokrasi yang sesungguhnya, yaitu suara rakyat yang tertinggi nilainya untuk mewujudkan demokrasi sebagai kedaulatan di tangan rakyat. Namun, konteks yang terjadi pada komunitas politik yaitu dari Calon Anggota DPRD Kabupaten Asahan, Dapil 1 masih tidak memahami esensi demokrasi radikal (kewarganegaraan demokratik). Sebab, Calon Legislatif memahami demokrasi itu permainan kapital (liberal), maka dari itu, pemberian tuntutanan bagi warga dalam memaknai dan memperjuangkan hak-hak dan kewajibannya terkait PILEG Kabupaten Asahan di DAPIL 1 adalah hak yang tidak terlalu penting.

\section{Tidak Ada Ruang Pemisah Antara Privat (Kebebasan Individu) Publik}

Menurut Mouffe dalam Suryadinata, (2017 : 23) bahwa Konsep kewarganegaraan melalui identifikasi subjek politik dengan komunitas politiknya berdasarkan prinsip kebebasan dan kesetaraan bertujuan membentuk suatu kita. Pada konteks masyarakat di Kelurahan Kisaran Naga bahwa konsep kebebasan sebagai warga dalam pandangan politik terhadap PILEG 2019 menjadi basis yang kuat, akan tetapi basis kebebasan yang tampil bukan menunjukkan kebebasan yang membangun demokrasi radikal (demokratik), tetapi yang terjadi adalah kebanyakan warga lebih memilih tidak aktif dalam berlangsungnya PILEG Kabupaten Asahan yang bebas dari politik identitas dan politik uang. Pembentukan suatu "kita" sebagai warga negara yang mampu mengindentifikasi diri pada komunitas politik (pemerintah, legislatif (DPRD), LSM) tampak tidak berjalan. Sebab yang terjadi adalah warga masih membedakan antara publik dan privat. Artinya, warga masih menyatakan pekerjaan yang berhubungan dengan proses berjalannya PILEG Kabupaten Asahan adalah pekerjaan pemerintah dan orang-orang tertentu. Misalnya, pekerjaan KPPS (Kelompok Penyelenggara Pemungutan Suara) menurut warga Kisaran Naga adalah bukan tanggung jawab warga, akan tetapi kepentingan pemerintah dan warga korporat (kelurahan/KPU).

Kontekstual yang terjadi pada warga di Kelurahan Kisaran Naga dalam memahami PILEG Kabupaten Asahan di Dapil 1 masih bersifat pada kewarganegaraan liberal. Artinya, warga negara masih memahami PILEG sebagai gerakan kapitalis (politik uang), gerakan politik identitas (agama, suku (marga)) sehingga kondisi itu berdampak pada pemahaman warga untuk tidak terlalu memberikan kepedulian tinggi pada berjalannya PILEG yang demokratik. Gerakan untuk menolak politik uang sebagai basis gerakan kapitalis memang terlihat pada 1 subjek informan, akan tetapi kondisi itu pun tetap jatuh pada pilihan warga tersebut yang memilih Caleg berdasarkan politik identitas. Jadi, kewarganegaraan liberal masih cukup kuat dalam tradisi warga di Kelurahan Kisaran Naga. 


\section{KESIMPULAN}

Politik kewarganegaraan liberal masih mengakar pada masyarakat di Kelurahan Kisaran Naga. Kondisi itu dapat dilihat dari PILEG DAPIL 1 Kabupaten Asahan dianggap warga sebagai ruang kapital (politik uang), basis politik identitas, basis kekeluargaan, basis kepentingan pribadi dan kelompok warga. Warga masih jauh dalam memahami karakteristik kewarganegaraan demokratik yaitu :

1. warga sebagai subjek yang pasif dalam mengidentifikasi diri dalam komunitas politik (pemerintah, DPRD, LSM).

2. Komunitas politik (Kelurahan, DPRD, LSM) belum memberikan tuntunan atau pedoman bagi warga Kisaran Naga dalam menyikapi PILEG 2019. c. warga Kisaran Naga masih memisahkan ruang privat (kebebasan individu) dan publik. Artinya, warga sering mengganggap bahwa kewajiban warga selesai pada saat mencoblos, hak warga untuk tidak mencoblos atau tidak terlibat pada KPPS. Sesungguhnya, memisahkan ruang privat dan publik merupakan ketegangan permanen yang tidak pernah bisa didamaikan. Maka dari itu, ketegangan antara konsep kebebasan dan kesetaraan dalam memahami tugas dan kewajiban pada diri sebagai individu dan warga sebagai bagian negara dalam menyikapi PILEG 2019 di Dapil 1 Kabupaten Asahan merupakan karakter demokrasi modern (kewarganegaran liberal/pasar).

3. Kontekstual konsep kewarganegaraan demokratik pada warga di Kelurahan Kisaran Naga yaitu seharusnya peran komunitas politik (Kelurahan Kisaran Naga, DPRD Fraksi PKPI Dapil 1 Kabupaten Asahan, LSM) memberikan pendidikan politik tekait PILEG 2019 pada warga, tetapi tetap memberikan kebebasan pada warga dalam menentukan pilihan Caleg nya, tanpa ada kooptasi dan intervensi. Begitupun dengan warga, warga seharusnya menjadi warga negara yang aktif dalam memahami PILEG sebagai ruang demokratik, seperti mencari tahu jejak rekam Caleg, visi-misi Caleg, bidang yang dipahami Caleg, Rencana Caleg akan duduk di bidang apa jika terpilih di DPRD, apakah Caleg yang akan dipilih mampu menangkap aspirasi warga, dan memahami PILEG sebagai sarana yang menentukan kemajuan atau kemunduran daerah Kelurahan Kisaran Naga pada khususnya, dan Kabupaten Asahan pada umumnya.

\section{DAFTAR PUSTAKA}

Asnawi. 2016. Penegakan Hukum Tindak Pidana Politik Uang Pemilihan Umum Legislatif Pada Masa Kampanye Di Kabupaten Serang. Jurnal Mimbar Justitia, 2(2): 765-784

Creswell, John W. 2015. Penelitian Kualitatif dan Desain Riset Memilih di Antara Lima Pendekatan. Yogyakarta : Pustaka Pelajar

Denzin, Norman K dan Yvonna S. Lincoln. 2009. Terjemahan buku asli Handbook of Qualitative Research. Yogyakarta : Pustaka Pelajar

KPU. 2019. Hasil Hitung Suara Pemilu Legislatif DPRD Kab/KOTA 2019. https://pemilu2019.kpu.go.id/\#/dprdkab/hitung-suara/. 11 Februari 2020.

Liando, Daud M. 2016. PEMILU DAN PARTISIPASI POLITIK MASYARAKAT (Studi Pada Pemilihan Anggota Legislatif Dan Pemilihan Presiden Dan Calon Wakil Presiden Di Kabupaten Minahasa Tahun 2014). Jurnal LPPM Bidang EkoSosBudKum, 3(2): 14-28

Mouffe, Chantal. 1992. Democratic Politics Today. London : Verso

Pasaribu, Iyan ; Irfan Prayogi, 2018. Bekerjanya Politisasi Identitas Pada Pilkada Sumut 2018 (Menakar Pengaruh Isu Agama Terhadap Kemenangan Edy Rahmayadi Dan Musa Rajekshah. Jurnal Bawaslu, 4(1) : 11-28

Silalahi, Juli Natalia. 2018. Politik Pengakuan Intersubjektif : Perjuangan Komunitas Rumah Lanting atas Hak Menetap dan Hak Ekonomi sebagai Warga Negara di Kelurahan Pahandut Seberang Kota Palangka Raya. Yogyakarta : FISIPOL Universitas Gadjah Mada 
Suprianto, La Ode ; Muh. Arsyad, dan Megawati A. Tawulo. 2016. Persepsi Masyarakat Terhadap Politik Uang Pada Pilkada Serentak (Studi Di Desa Ronta Kecamatan Bonegunu Kabupaten Buton Utara). Jurnal Neo Societal, 2(1) : 1-10

Suryadinata, Theofilus Apolinarius. 2017. Artikulasi Politik Kewarganegaraan Dalam Gerakan Keadilan Lingkungan di Kalimantan Tengah. Tesis : UGM 